\title{
FOOD AND NUTRITION AWARENESS SYSTEMS IN THE CITY OF SURAKARTA
}

\section{Bambang Sigit Amanto, Sigit Prabawa, Kawiji and Bara Yudhistira}

Faculty of Agriculture Universitas Sebelas Maret, Jl. Ir. Sutami No.36A, Surakarta, 57126, Indonesia

Email: barayudhistira@staff.uns.ac.id

\begin{abstract}
Surakarta City is one of the cities in Central Java which is vulnerable to food insecurity events, especially transient food insecurity. This is because the city of Surakarta is a disaster-prone area from flooding, strong winds and landslides. This will have an impact on nutrition and food access for the people of Surakarta City when a disaster occurs. The role of the SKPG is very important in providing information for the Surakarta City government regarding the condition of food and nutrition, so that the response to food insecurity can be right on target. The SKPG is compiled by collecting data according to categories, which are then processed for policy making from the Surakarta City government. The quality of public food consumption in Surakarta City, Central Java is still far from ideal. This is indicated by the score of the Expected Food Pattern (PPH) which was still in the range of 80.8\% in 2016 which was even lower than 2014 which reached 90.3\%. However, in 2019 PPH for Surakarta City was 94\%, higher than the national target (92\%) based on SKPG annual report of Surakarta City 2019. Apart from the low level of public awareness, the economic condition of the residents can also be the cause of this low quality of food. The decreasing purchasing power of the people is directly proportional to their ability to meet the nutritional standards of the food they consume. The problem of low quality food consumption does not only occur in Central Java, but also nationally. The facts show that Indonesia is ranked the country with the worst food nutrition in the world. This is indicated by the still high number of children under five with weight and height not according to age, which is in the range of $37 \%$, obesity is $12 \%$, and thinness of $11 \%$, this has the potential to lead to greater stunting cases. The occurrence of food and nutrition insecurity is generally caused by not meeting the amount of agricultural production to meet food needs in the region. SKPG is implemented as a measure to anticipate and overcome food insecurity in Surakarta. SKPG should be able to become a guideline so that even distribution and improvement of food security can be done. Based on the explanation of these problems, it is necessary to develop a Food and Nutrition Precautions System in Surakarta City.
\end{abstract}

Keywords: Food, Nutrition, SKPG, Surakarta, Vigilance 


\section{INTRODUCTION}

Based on the Food Law Number: 18 of 2012 (Kementan, 2012) food security is a condition for the fulfillment of food for the state to individuals, which is reflected in the availability of sufficient food, both in quantity and quality, safe, diverse, nutritious, equitable and affordable and does not conflict with religion, belief, and community culture, in order to live a healthy, active and productive life in a sustainable manner. When food conditions for the state to individuals are not fulfilled, the condition that will occur is a condition of food insecurity, so that food insecurity can be interpreted as a condition where there is no sufficient food for individuals / individuals to be able to live healthy, active and productive in a sustainable manner. Food insecurity can also be defined as a condition when the household (household member) experiences malnutrition as a result of insufficient food availability (physical unavailability of food), and/ or the inability of the household to access sufficient food, or if the food is consumed (intake) is below the minimum number of calories required.

The occurrence of food insecurity conditions can be caused by many factors, but at least can be caused by, among others: (a) lack of economic access for individuals/ households to obtain sufficient food; (b) there is no physical access for individual households to obtain sufficient food; (c) insufficient food for a productive individual/ household life; and (d) food is not fulfilled sufficiently in quantity, quality, variety, safety and affordability of prices. In addition, food insecurity can be affected by people's purchasing power which is determined by their income level. Low levels of public income and reduced purchasing power of food will worsen people's consumption of energy and protein.

Given the complexity of the problem of food and nutrition, it is necessary to monitor the condition of food and nutrition in the city of Surakarta, one of which is the analysis of the Food and Nutrition Alert System (SKPG). SKPG is an analysis of possible food and nutrition problems, which includes a series of processes to anticipate food and nutrition insecurity events through collection, processing, storage, analysis and dissemination of information on food and nutrition situations.

\section{METHOD}

The method for determining the SKPG includes the following stages:

1. Activities to collect data/ information on food that affect nutritional status according to the indicators set, process and analyze in order to be aware of the threat of food and nutrition shortages in the community.

2. Formulation of policy planning and evaluation of food insecurity prevention.

3. Determining the policy for intervention actions in overcoming food insecurity and for intervening in case of a food crisis. 
4. To build coordination and cooperation between agencies and stakeholders as well as the community in handling programs for overcoming food and nutrition insecurity.

\section{RESULT AND DISCUSSION}

The success of the Food and Nutrition Precautions System (SKPG) in the prevention and control of food insecure areas in its implementation depends on the coordination between related agencies, support from the Regional Government and the commitment of the SKPG Team to carry out routine and sustainable SKPG activities. In carrying out SKPG activities, the SKPG Team has carried out collection, processing and analysis, the results of these activities can be used as a reference in carrying out intervention activities and other activities related to SKPG activities. The SKPG team holds meetings/ meetings to evaluate SKPG activities carried out by each related agency 3 (three) times a year. In addition, it needs coordination and synergy between various parties, both between related institutions and between the government and the community and the private sector. This coordination is intended to unify directions to improve food security and improve community nutrition in the city of Surakarta.

Surakarta City is a city in the former Surakarta residency which has 5 districts with a total area of 44.04 $\mathrm{km}^{2}$ of the area owned by $4.47 \%$ (197.6 Ha). Based on SKPG annual report of Surakarta City 2019, the land in Surakarta City still used for rice farming (rice), while the rest is in the form of dry land used for yards and buildings. The crops most cultivated by farmers are rice, secondary crops and a few vegetables. There is no type of fish that is cultivated in the city. Fish are supplied from the surrounding area and East Java. While the yard is used for the cultivation of fruits, livestock including cows, chickens, goats/sheep and ducks. Cows are mainly found in Banjarsari District while goats and sheep are in Banjarsari, Laweyan and Pasar Kliwon.

When viewed from the production aspect, food production in Surakarta City has not been able to meet the food needs of the population, so food shortages must be imported from outside the City of Surakarta. However, Surakarta is a City of Services and a City of Trade, especially for basic necessities. So that with an effective and efficient distribution system in the city of Surakarta, food availability will be available at any time.

In order to meet people's needs for basic needs and foodstuffs, of course, an adequate supply is needed, regardless of the supply that comes from the region itself or comes from outside the city of Surakarta. To facilitate the distribution of food channels that are needed by the community, a place that can be used as a transaction between sellers and buyers is needed, namely the market. With a market, people's food needs are easily obtained for their daily needs. In 2018 Surakarta there were 44 types of traditional markets (BPS, 2019). 


\section{Aspects of access to food}

Food is a basic need for humans to be able to sustain life and life, therefore adequate food for everyone, at all times is a human right that deserves to be fulfilled. The increase in food needs along with the increase in population must be supported by an increase in job opportunities in order to obtain a decent income so that access to food increases. This is a major component in the realization of food security.

The government must be able to create a conducive and efficient food distribution performance that can make a positive contribution, especially to the stability of food prices and maintain food supply conditions in a region. If the food commodity distribution system functions properly, then under normal conditions the food commodity distribution process will be able to move a food commodity from the producer area to the consumer area at any time in sufficient quantity and quality and at a price affordable to all people.

The main characteristic of food commodity production is that it is seasonal, perishable and generally the location of food producers is only concentrated in a few production center areas. In a certain time period, such as during the main harvest, where the production of food commodities is abundant, the price of food commodities will tend to fall or be cheap. Conversely, in a certain period of time food production decreases, the price of food commodities will tend to increase.
When there is a deficit, where food production sources have started to decrease and the resulting production is no longer sufficient for consumer needs. The market situation needs to be stimulated so that adequate inter-regional trade is achieved. Thus, the price level in that area does not exceed a certain level, which can be tolerated.

Likewise, on the other hand, when conditions in central areas where food production is experiencing a surplus, the price difference between regions must be maintained in such a way that the distribution can spread out and fill pockets in areas experiencing food shortages. In this case, the government is obliged to facilitate the distribution of excess food production so that an adequate price level can be maintained, both on the producer side and on the consumer side.

Food prices are an indicator that can explain the food security conditions of a region. For this reason, it is necessary to monitor the price of staple food needs (strategic food) to determine price developments. Price developments which tend to continue to rise greatly affect the purchasing power of the community, especially the basic needs of the community, which in turn will reduce the level of community welfare.

These price developments indicate constraints on supply, demand and the distribution system. From the analysis of the monthly food and nutrition situation based on the composite indicator of access to food, which compares the average percentage of the current month's 
price compared to the average price for the last 3 (three) months, for rice commodities it shows that most of the time there has been no significant increase in prices. stable (safe). Only in July did a rather large increase from Rp. 9,175, - in June and Rp. 12,250, - in July. This will result in conditions for July and further vigilance is warranted. However, the price of rice stabilized again in August (Rp. 9,275, -) and so on.

In general, this parameter of food access can be said that there is no significant fluctuation. Indeed, there was a significant increase in prices, from June to July. However, the following month the condition was relatively stable. This is probably due to events both national and regional which have a slight impact on market conditions. The amount of income also influences the determination of the diversity of food consumed (Hardinsyah, 2007).

\section{Aspects of food utilization}

Consumption of diverse, nutritionally balanced and safe foods can meet the nutritional adequacy of individuals to grow and develop. Benchmarks that can reflect the nutritional status of the community are the nutritional status of children under five as measured by body weight and height according to age and compared with WHO reference standards. Children who have a malnutrition or poor status (underweight) based on measurements of body weight for age $(\mathrm{BW} / \mathrm{U})$ and short or very short (stunting) based on measurements of height for age $(\mathrm{TB} / \mathrm{U})$ which are very low compared to WHO standards have a risk of loss level of intelligence or intelligence quotient (IQ) of 10-15 points.

Undernutrition of children under five and pregnant women will increase household and government spending on health costs because many residents fall sick easily due to malnutrition. In conditions of malnutrition, the decrease in individual productivity is estimated to be more than 10 percent of potential lifetime income. With improved food consumption and nutritional status, the number of poor people will decrease. Poverty alleviation efforts that can increase household access to food will have a great leverage in improving health and productivity. In fact, the state of nutrition of the mother at the time before and during pregnancy determines the quality of the baby (Cetin et al., 2009).

The inability to meet household food needs, especially for pregnant women and children under five, will result in malnutrition which results in the birth of unqualified young generations. The success of a nation's development is determined by the availability of quality human resources (HR), namely human resources who have a strong physical, strong mental, excellent health, and are agile and intelligent. Empirical evidence shows that this is largely determined by the amount and quality of food intake consumed. Malnutrition and malnutrition are directly influenced by food consumption and infectious diseases. Indirectly influenced by parenting styles, availability and consumption 
of various foods, socio-economic, cultural and political factors. Investment in nutrition plays an important role in breaking the vicious cycle of poverty and malnutrition as an effort to improve the quality of human resources. Problems that can be caused by malnutrition experienced by mothers during pregnancy, namely the fetus experiencing stunted growth, the baby has a low weight and other infant growth and development disorders and is at risk of causing infant death (Yongky et al., 2009).

Some of the adverse effects of malnutrition are low work productivity, lost school opportunities, and loss of resources due to high health costs. From the analysis of the monthly food and nutrition situation based on the composite indicators of food utilization which compares the percentage of children under five who gain weight $(\mathrm{N})$ compared to the number of underfives who are weighed (D), the percentage of children under five who are weighted (D), the percentage of children under five who do not gain weight in 2 consecutive weighing times (2T) compared to the number of underfives weighed (D) generally indicates a safe position. However, the composite score indicates a vulnerable position, as a result of the percentage of children under five who increase in weight $(\mathrm{N})$ compared to the number of underfives weighed (D) which indicates a vulnerable position. In addition, food diversity has a significant effect on stunting and underweight, especially in children (Widodo et al., 2017). Furthermore, the distribution of the Energy Adequacy Rate, Protein and PPH Score which is getting higher can increase the height of children under five by reducing the prevalence of stunting (Suryana et al., 2018). Protein is needed for growth, so it is necessary to diversify food products to meet protein needs for growth (Yudhistira et al., 2019).

The nutritional status of children (usually under 5 years of age) is a very good indicator to use in the food absorption. Factors that influence a child's nutritional status are the situation of food security at the household level, maternal nutritional and health status, maternal education, parenting styles, access to clean water, access to timely health services. Because in general, children like to eat delicious and refreshing snacks (Mulya et al., 2019). In addition, nutrition in children can be influenced by parenting, where more and more career women pay less attention to nutrition and health problems for their children. One example is the application of the wrong diet. This of course will affect the development of children, including underweight children under five. In addition, there is still a lack of socialization from the government regarding nutrition and health issues to the community, and there is still a lack of awareness of the community or mothers to always weigh their children in Posyandu, or do not weigh them every month, so that toddlers' weight gain is not controlled every month. So it is necessary to fulfill nutrition to avoid nutritional imbalances that will have 
an impact on other nutritional problems (Rokhmah et al., 2016). Increased income and education levels cause the hope food pattern $(\mathrm{PPH})$ to increase as well (Argandi et al., 2019). In addition, the number of children in the family affects the nutritional status of the child (Sebataraja et al., 2014). Food improvement can be carried out by implementing programs, one of which is the introduction of food production process technology that meets ASUH processed food quality management (safe, healthy, intact and halal) (Nurhartadi et al., 2018). Solutions to improve the food processing process need to be considered by applying adequate sanitation and hygiene standards as well as adequate storage of raw materials and products. The breakfast factor has an effect on nutritional status, this is in accordance with research Puspitasari \& Rahmani (2018), states that the majority consuming the type of breakfast snack $(<15 \%$ RDA) with irregular frequency ( $<4$ times a week) and these data indicates that the nutritional knowledge obtained is not inherently immediately change the behavior of healthy living everyday. It is advisable to provide counseling about balanced nutrition for adolescents to increase their intake of energy, protein, fat and carbohydrates. Respondents are expected to pay attention anthropometry of his body to determine his nutritional status and health risks (Rahmawati, 2017).

\section{CONCLUSION}

The aspect of food access or affordability shows that most subdistricts in Surakarta City have safe indications (score 1) during 2019. Only in July showed indications of vulnerability (score 3). There are many reasons that cause the price of rice to rise, which in June amounted to Rp. 9,175, to Rp. 12.250,- per kg in July. But for the next month it's relatively stable again.

\section{REFERENCES}

Argandi, S., Trimo, L., Noor, T.I., (2019). Faktor-Faktor Yang Mempengaruhi Pola Pangan Harapan (PPH) Di Kabupaten Bandung. Agroinfo Galuh 6, 132.https:// doi.org/10.25157/ji mag.v6i1.1506

BPS. (2019). Kota Surakarta Dalam Angka 2019.

Cetin, I., Berti, C., Calabrese, S. (2009). Role of micronutrients in the periconceptional period. Hum. Reprod. Update 16, 80-95. https://doi.org/10.1093/humup d/dmp025

Hardinsyah, H. (2007). Review Faktor Determinan Keragaman Konsumsi Pangan. J. Gizi dan Pangan 2, 55. https:// doi.org/10.25182/jgp.20 07.2.2.55-74

Kementan. (2012). Undang-Undang Republik Indonesia Nomor 18 Tahun 2012 tentang Pangan. Kementerian Pertanian Republik Indonesia, Jakarta.

Mulya, Z, A., Abdi Nusara, A., Vidya Anggraini, C., Wandhira 
Wimarnaya, V., Fadhila, N., Yudhistira, B. (2019). Prospek Pengembangan Es Gabus Buah Dan Sayur, Cita Rasa Jadul Kaya Vitamin. J. Kewirausahaan dan Bisnis 24, 12. https:/ /doi.org/10.20961/jkb.v2 $4 \mathrm{i} 13.30646$

Nurhartadi, E., Anandito, R.B., Yudhistira, B. (2018). IbM Tahu Bakso "Asuh" Di Kecamatan Boyolali Kabupaten Boyolali. J. Kewirausahaan dan Bisnis 21, 1121.

https://doi.org/10.20961/jkb.v2 $1 \mathrm{i} 11.20834$

Puspitasari, D.I., Rahmani, A. (2018). Gambaran Kebiasaan Sarapan Dan Status Gizi Mahasiswa Gizi Dan Non-Gizi Universitas Muhammadiyah Surakarta. MPPKI (Media Publ. Promosi Kesehat. Indones. Indones. J. Heal. Promot. 1, 46-51. https:/ / doi.org/10.31934/mppki .v1i2.161

Rahmawati, T. (2017). Hubungan Asupan Zat Gizi Dengan Status Gizi Mahasiswa Gizi Semester 3 Stikes Pku Muhammadiyah Surakarta. Profesi (Profesional Islam. Media Publ. Penelit. 14, 49. https:/ / doi.org/10.26576/ profesi .148

Rokhmah, F., Muniroh, L., Nindya, T.S. (2016). Dengan Status Gizi Siswi Sma Di Pondok Pesantren Al-Izzah Kota Batu. Media Gizi Indones. 11, 94-100.

Sebataraja, L.R., Oenzil, F., Asterina, A. (2014). Hubungan Status Gizi dengan Status Sosial Ekonomi
Keluarga Murid Sekolah Dasar di Daerah Pusat dan Pinggiran Kota Padang Lisbet Rimelfhi Sebataraja,. J. Kesehat. Andalas 3, 182-187.

https:// doi.org/10.25077/jka.v3i 2.81

Suryana, S., Roudza, R., Alfridsyah, A. (2018). Konsumsi pangan dan skor pola pangan harapan (PPH) dengan prevalensi stunting di Provinsi Aceh (Data Susenas dan PSG tahun 2016). AcTion Aceh Nutr. J. 3, 149. https://doi.org/10.30867/action. v3i2.116

Widodo, Y., Sandjaja, Ernawati, F. (2017). Score of Desirable Dietary Pattern and Association with Nutritional Status of 0.5-12-Year Old Indonesian Children. Penelit. Gizi dan Makanan 40, 63-75.

Yongky, Y., Hardinsyah, H., Gulardi, G., Marhamah, M. (2009). Status Gizi Awal Kehamilan Dan Pertambahan Berat Badan Ibu Hamil Kaitannya Dengan Bblr. J. Gizi dan Pangan 4, 8. https://doi.org/10.25182/jgp.20 09.4.1.8-12

Yudhistira, B., Eristanto, D. (2019). Karakteristik Kimia, Fisik Dan Sensoris Keripik Simulasi Berbahan Dasar Ikan Bandeng (Chanos Chanos) Dan Tepung Kacang Merah (Phaseolus vulgaris L.) Sebagai Makanan Ringan Sumber Protein. J. Teknol. dan Ind. Pertan. Indones. 11, 46-52. 